\author{
Asep Sufyan, Ari Suciati \\ Program Studi Desain Produk \\ Universitas Telkom \\ krackers@telkomuniversity.ac.id
}

\title{
PERANCANGAN SARANA PENDUKUNG LESEHAN AKTIVITAS RUMAH TANGGA
}

\begin{abstract}
Abstrak. Lesehan merupakan suatu istilah yang budayanya berasal dari tata karma duduk, sikap duduk seseorang di negara Indonesia sangat menentukan tata karma. Lesehan merupakan budaya yang menunjukkan sifat kesederhanaan, kesetaraan, dan kebersamaan yang didasarkan pada rasa persaudaraan. Istilah lesehan yaitu cara duduk di atas lantai, dengan posisi duduk yang alternatif yang biasa dipakai sehari - hari saat di rumah, karena lesehan dianggap lebih bebas dan menyenangkan, namun posisi duduk ini cenderung kurang formal.

Sikap duduk lesehan memiliki banyak gaya atau sikap diantaranya duduk dengan bersila, bersimpuh, selonjoran, kaki menyilang dengan posisi badan bersandar atau pun tidak bersandar. Posisi gaya atau sikap ini tidak selamanya tetap, karena posisi duduk ini cenderung mengubah - ubah gaya atau sikap, dimana dalam setiap perubahan posisi gaya dapat ditemukan rasa nyaman tersendiri. Setiap gaya lama - kelamaan juga dapat menimbulkan rasa tidak nyaman, seperti pegal, kesemutan, kesulitan berdiri akibat dari terlalu lama duduk, sakit punggung, dan sesekali ingin bersandar untuk menghilangkan rasa pegal.

Perlu sebuah perancangan produk yang bisa memfasilitasi kebiasaan seseorang dalam kebiasaannya ketika duduk lesehan. Perancangan ditinjau dari aspek ergonomi yang berfokus kepada titik lelah seseorang ketika berkaktivitas.
\end{abstract}

Kata kunci: Perancangan, Sikap, lesehan.

\begin{abstract}
Lesehan is a cultural term derived from the sitting karma system, the sitting position of a person in the Indonesian state is crucial to the karmic order. Lesehan is a culture that shows the nature of simplicity, equality, and togetherness based on the sense of brotherhood. The term lesehan is how to sit on the floor, with an alternative sitting position that is used everyday at home, because lesehan is considered more free and fun, but this sitting position tends to be less formal.
\end{abstract}

Sitting attitude lesehan has many styles or attitudes such as sitting with cross legs, kneeling, selonjoran, legs crossed with a lean body position or not leaning. Position of this style or attitude is not always fixed, because this sitting position tends to change - change the style or attitude, where in each style position changes can be found a sense of comfort itself. Any old style - over time also can cause discomfort, such as sore, tingling, difficulty standing up from sitting too long, back pain, and occasionally want to lean to relieve pain.

Need a product design that can facilitate a person's habits in the habit when sitting lesehan. Design in terms of aspects of ergonomics that focuses on a person's tired point when on the move.

Keyword: Design, Attitude, lesehan.

\section{PENDAHULUAN}

Lesehan cukup popular di negara Indonesia, tidak hanya dilakukan saat dirumah, baik warung, café , restoran, hingga tempat wisata ada yang menyediakan fasilitas untuk duduk lesehan. Lesehan dapat membentuk suasana duduk yang nyaman dan santai. Banyak sarana 
pendukung yang memfasilitasi posisi duduk ini, diantaranya karpet, bantal, tikar, dan kursi, dimana peran dari sarana tersebut untuk memberikan kenyamanan lebih bagi orang yang duduk lesehan.

Banyak aktivitas yang dapat dilakukan dengan posisi duduk ini, seperti halnya aktivitas yang dilakukan di rumah sebagai contoh aktivitas membaca, menonton televisi, belajar, dan lain sebagainya, bahkan saat - saat santai ketika hari libur atau sepulang sekolah, kerja, atau sepulang dari aktivitas di luar rumah. Bagi balita, anak - anak, remaja, dan dewasa hingga orang tua baik laki - laki atau perempuan banyak melakukan aktivitas yang di dukung dengan posisi duduk lesehan ketika di rumah.

Lesehan merupakan cara duduk di atas lantai tanpa alas. Lesehan cukup popular di negara Indonesia, tidak hanya dilakukan saat dirumah, baik warung, café , restoran, hingga tempat wisata ada yang menyediakan fasilitas untuk duduk lesehan. Lesehan dapat membentuk suasana duduk yang nyaman dan santai. Banyak sarana pendukung yang memfasilitasi posisi duduk ini, diantaranya karpet, bantal, tikar, dan kursi, dimana peran dari sarana tersebut untuk memberikan kenyamanan lebih bagi orang yang duduk lesehan.

Tidak hanya pinggang dan pantat, bagian lutut dan kaki pun perlu diperhatikan. Setelah dilakukan uji coba bagian tersebut juga mengalami atau mendapatkan effek buruk dari posisi duduk lesehan yang dilakukan. Jika diperhatikan lebih detail sebenarnya banyak bagian tubuh yang mengalami effek buruk dadi duduk lesehan, akan tetapi bagian - bagian pokok saja yang kiranya mendapatkan fasilitas untuk menunjang seseorang agar tetap nyaman dan terhindar dari effek buruk duduk lesehan.

Oleh karena itu, berdasarkan uraian diatas, perlu adanya perancangan sarana pendukung duduk lesehan, yang mendukung seseorang agar tubuh tetap dalam posisi sempurna saat melakukan posisi duduk lesehan. Secara umum sudah banyak sarana pendukung yang memfasilitasi cara duduk ini, akan tetapi sarana yang ada belum sepenuhnya memfasilitasi bagian - bagian tubuh seseorang yang menjadi tumpuan ketika duduk lesehan atau duduk di atas lantai. Sarana yang sudah ada kebanyakan hanya memperhatikan bagian pinggang dan pantat. Setelah dilakukan percobaan hasil yang dirasakan bahwa tidak bagian pinggang dan pantat saja yang memerlukan fasilitas, ada beberapa bagian lagi yang perlu diperhatikan.

Perlu adanya suatu sarana yang dapat memfasilitasi seseorang ketika duduk lesehan, dan sarana yang mampu memberikan kenyamanan lebih saat duduk lesehan. Sarana yang dapat memfasilitasi bagian - bagian tubuh yang menjadi titik tumpu ketika duduk lesehan, seperti halnya merancang sebuah sarana dimana pada sarana tersebut terdapat bagian atau part yang memfasilitasi bagian pinggang, pantat, lutut, dan kaki, seperti adanya sandaran untuk pinggang, alas duduk yang nyaman untuk pantat, alas yang fleksibel sesuai dengan posisi gerak kaki.

\section{METODE PENELITIAN}

Teknik analisis yang digunakan pada perancangan sarana pendukung lesehan ini dengan metode secara kualitatif yaitu mengikuti hasil dari teknik pengumpulan data yang digunakan sebelumnya, yang diutamakan adalah penilaian mengenai bagaimana penilaian mengenai permasalahan saat seseorang melakukan posisi duduk lesehan.

Pada proses selanjutnya yaitu proses perancangan maka metode penelitian yang digunakan adalah metode penelitian eksperimen atau percobaan. Eksperimen adalah sebuah kegiatan 
observasi di bawah kondisi buatan yang diatur oleh peneliti. Tujuan dari penelitian eksperimental adalah mengetahui apakah ditemukan kejanggalan ataupun penyelesaian masalah dari masalah yang sedang diteliti.

Pada kasus ini adalah solusi bagaimana merancang sarana pendukung yang memperhatikan postur tubuh seseorang ketika duduk lesehan dan memperhatian bagian tubuh mana saja yang mendapatkan banyak tekanan atau yang banyak berperan ketika melakukan duduk lesehan. Eksperimen dan studi model dilakukan untuk menguji apakah hipotesis yang dilakukan sudah benar atau perlu dilakukan pengkajian ulang.

Pada perancangan sistem dimaksudkan untuk mengetahui aspek apa saja yang perlu diketahui untuk merancang sebuah sarana pendukung yang memfasilitasi seseorang ketika duduk lesehan. Dari segi desain dapat dikelompokkan menjadi kategori visual:

\section{Bentuk}

Bentuk adalah suatu unsur dari desain yang memiliki suatu dimensi (panjang, lebar, tinggi) atau biasa disebut volume. Bentuk dibagi menjadi beberapa jenis, salah satunya yaitu bentuk geometris atau bentuk yang terukur misalnya kubus, tabung, limas, kerucut dan lain sebagainya. Selain itu ada juga bentuk organis yaitu bentuk yang dapat berubah atau berkembang dan tidak terukur misalnya bentuk tumbuhan, batu, dan lain sebagainya.

\section{Material}

Menurut Kamus Besar Bahasa Indonesia, material adalah bahan yang dipakai untuk membuat barang lain. Ada beberapa jenis material yang digunakan untuk membuat produk. Secara umum, material terbagi atas dua jenis yaitu material logam dan material non-logam dan kedua jenis material tersebut masih terbagi dari beberapa jenis yang berbeda.

Material non logam terbagi atas material alam dan buatan. Material alam terdiri dari kayu, batu, keramik, kulit, dan karet alam. Kayu adalah bahan mentah yang diperoleh dari hasil pemungutan pohon - pohon di hutan yang mudah di proses untuk dijadikan barang sesuai dengan kemajuan teknologi.

Pada perancangan ini akan digunakan material : kayu buatan (multipleks), logam stainless steel jenis monel, kulit sintetik (oscar), dan busa (yellow dan SK (putih)).

\section{Warna}

Sebagaimana yang telah dikemukanan oleh J. Linschoten dan Drs. Mansyur dan Henry Dreyfuss bahwa warna memiliki peran penting dalam membangun persepsi dalam pikiran manusia. Persepsi tersebut dapat menimbukan reaksi yang bermacam. Untuk itu perlu dipertimbangkan pemilihan warna yang tepat untuk membangun persepsi agar sesuai dengan yang ingin dikomunikasikan. Untuk itu warna digunakan untuk mempertegas maksud dari suatu symbol. Setiap warna mampu memberikan kesan dan identitas tertentu sesuai kondisi sosial pengamatnya. Warna mempunyai empat pengelompokan warna, yaitu warna panas, dingin, netral, dan kontras.

\subsection{FAKTOR KELELAHAN PENGUKURAN DAN PENGATURAN JADWAL WAKTU KERJA}

Kelelahan akibat kerja sering kali diartikan sebagai proses menurunnya efisiensi, performans kerja, dan berkurangnya kekuatan atau ketahanan fisik tubuh untuk terus melanjutkan 
kegiatan yang harus dilakukan. Ada beberapa macam kelelahan yang dikenal dan diakibatkan oleh faktor - faktor yang berbeda - beda seperti :

\section{Lelah Otot}

Yang dalam hal ini bisa dilihat dalam bentuk munculnya gejala kesakitan yang sangat amat sangat ketika otot harus menerima beban yang berlebihan.

\section{Lelah Visual}

Yaitu lelah yang diakibatkan ketegangan yang terjadi pada organ visual (mata). Mata yang terkonsentrasi secara terus menerus pada suatu objek (layar monitor) seperti yang dialami oleh operator komputer, misalnya akan terasa lelah. Cahaya yang terlalu kuat yang mengenai mata juga akan bisa menimbulkan gejala yang sama.

\section{Lelah Mental}

Kelelahan bukan diakibatkan secara langsung oleh aktivitas fisik, melainkan lewat kerja mental (proses berfikir). Sering diakibatkan oleh lelah otak.

\section{Lelah Monotoris}

Jenis kelelahan yang disebabkan oleh aktivitas kerja yang bersifat rutin, monoton, atau lingkungan kerja yang sangat menjemukan. Dari jenis kelelahan yang telah diuraikan , maka timbulnya rasa lelah dalam diri manusia merupakan proses yang terakumulasi dari berbagai faktor penyebab dan mendatangkan ketegangan yang dialami oleh tubuh manusia. Untuk menghindari akumulasi yang terlalu berlebihan, diperlukan adanya keseimbangan antara masukan sumber datangnya kelelahan tersebut (faktor - faktor penyebab kelelahan).

Proses pemulihan dapat dilakukan dengan cara antara lain memberikan waktu istirahat yang cukup baik yang terjadwal atau terstruktur atau tidak akan seimbang dengan tinggi rendahnya tingkat ketegangan kerja.

\subsection{ANALISA DENGAN ASPEK ERGONOMI}

Ergonomi termasuk dalam disiplin ilmu yang menyertakan keselamatan, keamanan,dan kenyamanan. Ergonomi berkenaan juga dengan optimasi, efisiensi, kesehatan, keselamatan, dan kenyamanan manusia di tempat kerja, di rumah dan tempat rekreasi. Ergonomi studi tentang interaksi antara manusia, fasilitas dan lingkungannya dengan tujuan utama yaitu menyesuaikan suasana kerja dengan manusianya.

Pertimbangan aspek ergonomi yaitu penganalisaan dan pertimbangan interaksi antara manusia dengan produk dan lingkungan kerjanya. Aktivitas manusia pada saat menggunakan produk yang berupa sikap dan gerakan tubuh akan berdampak pada kondisi tubuh manusia.

Gerakan - gerakan yang tidak tepat ataupun tidak sesuai dengan sistem tubuh manusia akan menyebabkan ketidaknyamanan dan bahkan menimbulkan rasa sakit atau gangguan pada tubuh manusia. Rancangan suatu produk harus dapat memberikan kepuasan pada pemakai baik dari segi ergonomi visual (bentuk, warna, material) dan ukuran produk (menurut antropometri).

\section{Analisa}

\begin{tabular}{|l|l|l|}
\hline Teori Ergonomi & Solusi & Perancangan \\
\hline
\end{tabular}




\begin{tabular}{|c|c|c|}
\hline Lelah otot & $\begin{array}{l}\text { - Produk terukur } \\
\text { - Produk lebih simple } \\
\text { - Tidak terlalu banyak } \\
\text { fitur } \\
\text { - Tidak terlalu banyak } \\
\text { prosedur }\end{array}$ & $\begin{array}{l}\text { - Konsep perancangan yang digunakan } \\
\text { mengikuti data antropometri (rata - rata) } \\
\text { baik dari data antropometri penggunanya } \\
\text { atau produk yang menjadi tolok ukur. }\end{array}$ \\
\hline Lelah visual & $\begin{array}{l}\text { - Bentuk } \\
\text { - Warna } \\
\text { - Material }\end{array}$ & $\begin{array}{l}\text { - Bentuk } \\
\text { Konsep dari bentuk menyesuaikan } \\
\text { dengan postur tubuh manusia. } \\
\text { - Warna } \\
\text { Konsep perancangan warna memilih } \\
\text { warna yang disesuaikan dengan kegiatan } \\
\text { atau lingkungan. } \\
\text { - Konsep material yang digunakan yaitu } \\
\text { material yang dapat memberikan rasa } \\
\text { kenyamanan. }\end{array}$ \\
\hline Lelah mental & $\begin{array}{l}\text { - Kenyamanan (ruang } \\
\text { gerak, jarak jangkauan, } \\
\text { fokus) }\end{array}$ & $\begin{array}{l}\text { - Kenyamanan (ruang gerak, jarak } \\
\text { jangkauan, fokus) } \\
\text { - Perancangan menyesuaikan dengan / dari } \\
\text { bentuk perancangan produk yang } \\
\text { disesuaikan dengan data antropometri } \\
\text { rata - rata / secara umum baik dari } \\
\text { pengguna atau prosuk yang menjadi } \\
\text { tolok ukur. }\end{array}$ \\
\hline Lelah monotoris & $\begin{array}{l}\text { - Fleksibel } \\
\text { - Praktis } \\
\text { - Efektif } \\
\text { - Efisien }\end{array}$ & $\begin{array}{l}\text { - Produk mudah disimpan } \\
\text { - Produk mudah dipindahkan } \\
\text { - Produk mudah digunakan }\end{array}$ \\
\hline
\end{tabular}

Tabel 1 Analisis Produk

(Sumber: Dokumentasi Pribadi, 2015)

\section{LANDASAN EMPIRIK}

Dalam perancangan sebuah produk selain menentukan sasaran, dalam proses desain harus menentukan pengembangan produk. Dalam pengembangan produk ini, bergantung pada masalah yang telah dirumuskan. Selain itu ditentukan pula aspek - aspek yang perlu dikaji untuk membantu mengolah hasil perancangan yang akan dibuat. Analisis produk yang dirancang dilihat dari berbagai aspek seperti berikut :

\section{Aspek Fungsi}

Pertimbangan aspek fungsi yaitu penganalisaan setiap pemecahan masalah suatu produk kearah layak guna (tepat guna) sehingga bermanfaat bagi pemakainya. Pendapat ini menunjukkan bahwa pertimbangan aspek fungsi sangat diutamakan, karena desain pada hakikatnya untuk membantu memecahkan masalah yang dihadapi oleh manusia. Fungsi dalam desain merupakan wujud realitas pertama dari suatu mata rantai sebuah perancangan. Aspek fungsi sebagai esensi filosofi perlu dipegang erat sebagai alat kontrol perancangan. Jika alat control lemah, maka hasil akhirnya yaitu muncul desain yang lemah, atau tidak sesuai dengan konsep awal. Oleh karena itu, setiap desain haruslah memiliki fungsi yang jelas. 
Penetapan suatu fungsi tertentu, atas suatu produk yang sedang dirancang, seharusnya dibuat oleh perancang sejak awal. Dalam hal ini, keputusan tentang fungsi yang dikehendaki, harus merupakan keputusan yang sangat jelas, sehingga dalam proses perancangan aspek fungsi tersebut dijadikan sebagai persyaratan desain (design requirement) atau batasan desain (design constrain ). Aspek fungsi juga berkaitan dengan keselamatan manusia. Sebagai desain harus memiliki fungsi melindungi manusia baik secara fisiologis maupun psikologis baik bagi pengguna maupun orang yang ada disekitarnya.

Ditinjau dari aspek fungsinya, produk sarana pendukung lesehan dirumah ini memiliki fungsi untuk memfasilitasi seseorang khususnya wanita ketika melakukan aktivitas dengan sikap duduk lesehan saat dirumah. Diketahui bahwa sikap duduk lesehan memiliki banyak gaya atau sikap, sehingga perlu adanya sebuah sarana yang berfungsi untuk memecahkan masalah dari setiap sikap duduk lesehan yang digunakan.

\section{Aspek Operasional}

Pada produk sarana lesehan ini ada beberapa alternatif oprerasional yang memungkinkan untuk digunakan saat posisi duduk lesehan, dimana alternatif ini berupa sistem sandaran yang dapat diposisikan sesuai dengan kenyamanan pengguna, sistem magnet yang memperkuat antara part satu dengan part lainnya saat produk di simpan atau tidak dalam posisi digunakan, dan sistem tekuk yang ada pada bagian lutut. Tahapan cara kerja dari produk sarana lesehan ini adalah :

A. Pengambilan produk dari tempat penyimpanan (Produk merupakan produk foldable, dimana produk menggunakan sistem lipatan dalam proses penyimpanannya, untuk menghemat ruang simpan).

B. Produk masih dalam keadaan terlipat.

C. Produk dibuka.

D. Produk ditempatkan pada space ruang yang cenderung luas atau saat akan menggunakan produk pastikan space ruang cenderung luas.

E. Sandaran pada produk diatur sesuai keinginan pengguna. Sandaran pada produk dapat diatur sebagaimana kenyamanan yang diinginkan oleh pengguna. Baik dalam sistem sandaran.

F. Produk dapat langsung digunakan untuk aktivitas indoor di dalam rumah, seperti membaca buku, dan lain sbeagainya.

\section{Aspek Produksi}

Pertimbangan aspek produksi yaitu penganalisaan dan pertimbangan setiap perancangan kearah efisiensi dan efektivitas produk agar mampu menyesuaikan diri dengan kondisi yang ada. Desain harus memungkinkan untuk diproduksi sesuai dengan metode dan proses yang tela ditentukan. Untuk itu perlu mempertimbangkan:

\section{A. Material}

Material yang digunakan pada perancangan sarana lesehan ini dibagi menjadi 4 material, yaitu :

1. Busa

Busa digunakan adalah busa jenis busa yellow dan busa SK (bus aputih). Busa digunakan pada keseluruhan produk, dimana produk yang dirancang mengharuskan produk nyaman saat digunakan. Busa yang digunakan adalah jenis busa pada umumnya dna pada perancangan ini ketebalan busa yang digunakan adalah ketebalan $8 \mathrm{~cm}$ dan $5 \mathrm{~cm}$. 


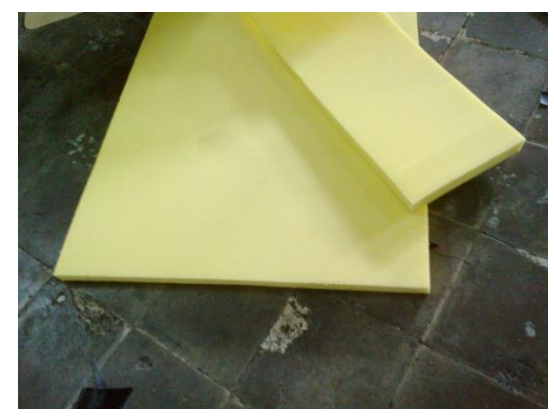

Gambar 3.1 Busa

2. Kulit Sintetik (oscar)

(Sumber: Dokumentasi Pribadi, 2015)

Kulit sintetik dipilih sebagai bahan pembungkus busa. Kulit sintetik dipilih dengan alasan kemudahan dalam membersihkannya, mengingat produk ini berhubungan langsung dengan lantai, sehingga dikhawatirkan produk mudah kotor atau berdebu.

Gambar 3.2 Kulit Sintetik (oscar)

(Sumber: Dokumentasi Pribadi, 2015)

3. Multiplek

Multiplek digunakan sebagai rangka pada bagian sandaran dan bagian alas duduk produk. Multipleks yang digunakan yaitu dengan ketebalan $8 \mathrm{~mm}$.

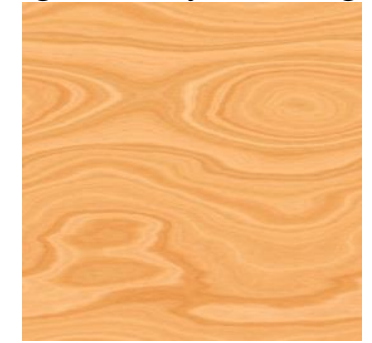

Gambar 3.3 Multiplek

(Sumber: Dokumentasi Pribadi, 2015)

4. Stainless steel

Stainless steel digunakan sebagai rangka penahan yang terpasang pada sandaran produk. Stainless steel didesain sedemikian rupa untuk menggantikan peran reclining seat. Stainless steel yang digunakan adalah jenis monel, sedangkan untuk penggunaannya yaitu jenis pipa dan solid. 


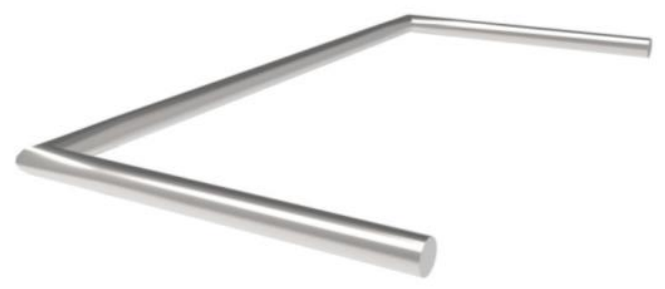

Gambar 3.4 Stainless Steel

(Sumber: Dokumentasi Pribadi, 2015)

B. Komponen

Perangkaian komponen pada produk ini menggunakan penghubung kain, dengan maksud karena sifat kain yang digunakan bersifat lentur dan fleksibel. Komponen pada produk ini ada 4 bagian produk (sandaran, alas duduk, dan 2 alas tambahan) dan komponen tambahan yaitu penahan (reclining seat manual) yang terpasang pada bagian belakang sandaran serta bantalan untuk kaki.

C. Tahapan Produksi

Tahapan proses produksi untuk produk ini adalah sebagai berikut :

1. Menyiapkan segala peralatan dan material yang digunakan

2. Membuat rangka untuk sandaran dan alas duduk.

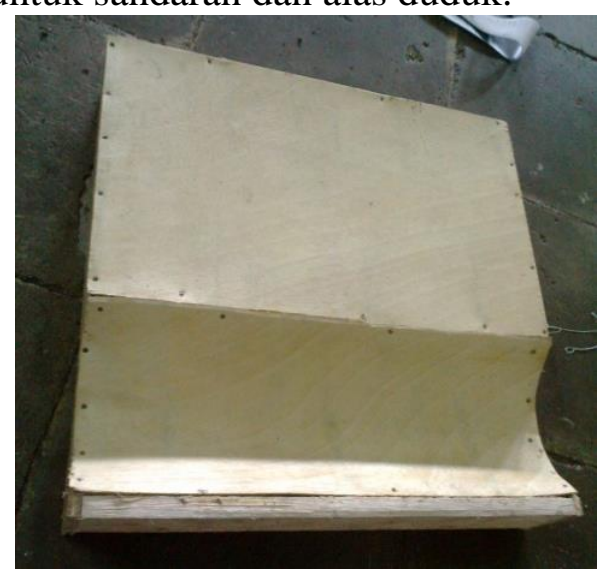

Gambar 3.5 Rangka Sandaran

(Sumber: Dokumentasi Pribadi, 2015)

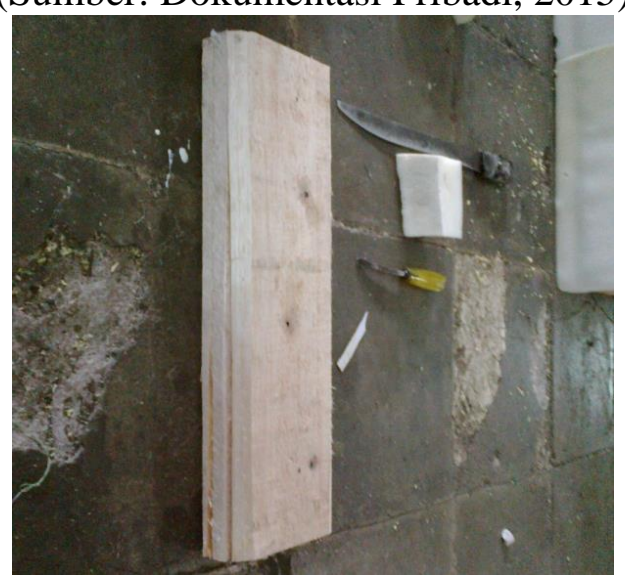

Gambar 3.6 Rangka Dudukan

(Sumber: Dokumentasi Pribadi, 2015) 
3. Melapisi seluruh bagian rangka dengan busa SK atau busa putih.

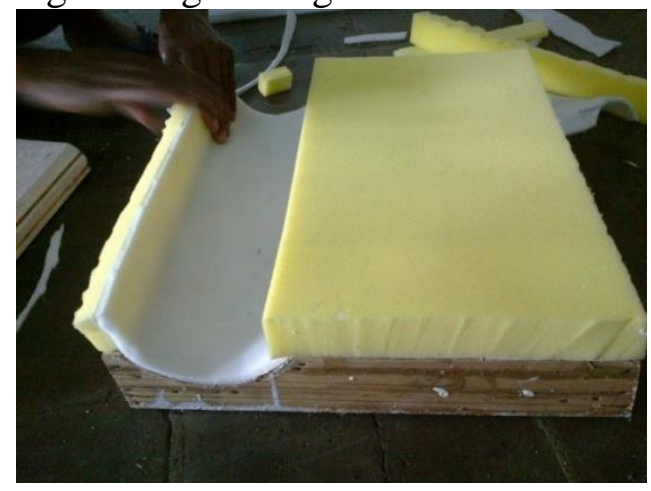

Gambar 3.7 Proses Pelapisan

(Sumber: Dokumentasi Pribadi, 2015)

4. Pemotongan busa yellow dengan ukuran yang sudah ditentukan.

5. Membuat pola ada kain dan pemotongan bahan (kain sintetik) .

6. Kain yang sudah dipotong disatukan (dijahit).

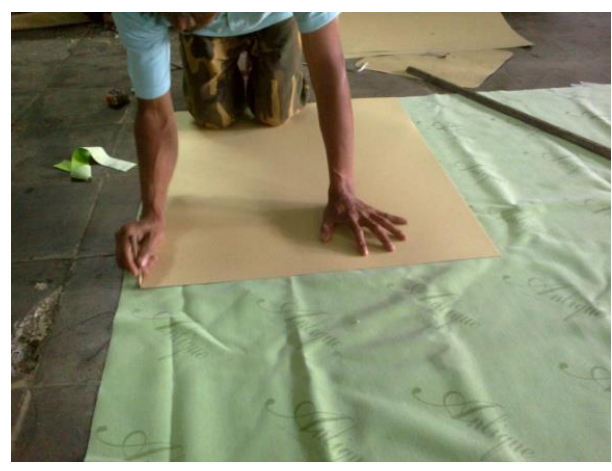

Gambar 3.8 Pembuatan dan Pemotongan Pola (Sumber: Dokumentasi Pribadi, 2015)

7. Menyatukan bagian busa dengan kain.

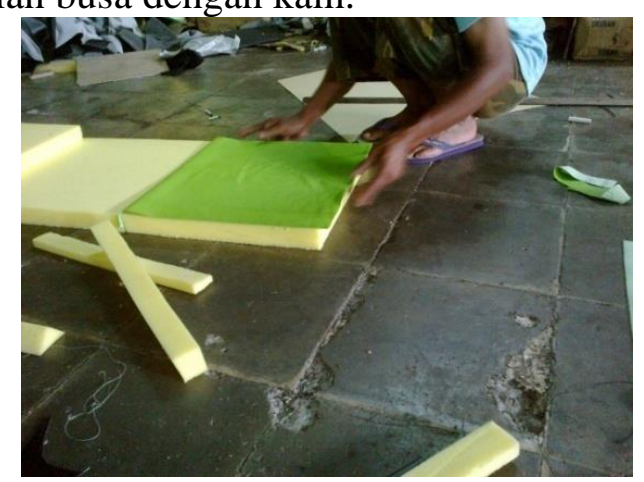

Gambar 3.9 Penyatuan Busa dan Kain

(Sumber: Dokumentasi Pribadi, 2015)

8. Proses pembuatan penahan stainless steel. 


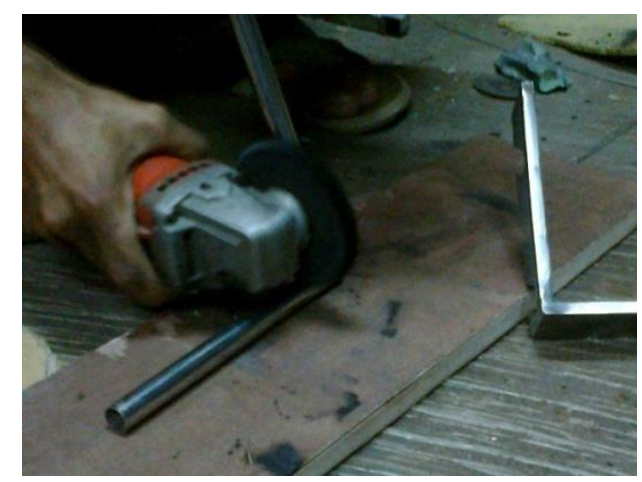

Gambar 3.10 Proses Stainless Steel

(Sumber: Dokumentasi Pribadi, 2015)

9. Stainless steel di potong sesuai dengan kebutuhan.

10. Stainless steel di satukan dengan proses las tig dengan gas argon.

11. Stainless steel yang menjadi penahan pada bagian bawah sandaran dibor dengan besar mata bor 1.75 inc.

12. Tahapan finishing stainless steel dengan menggunakan amplas besi, selanjutnya dengan amplas 400, dan selanjutnya diamplas dengan amplas besi dan langsol merah (untuk menghilangkan bagian yang hitam) dan terakhir di amplas dengan kain jeans dan langsol hijau (untuk mebuat stainless steel menjadi bening).

13. Tahapan finishing, penambahan aksesoris yang dibutuhkan berupa resleting dan perekat.

D. Waktu Produksi

Waktu produksi yang dibutuhkan untuk memproduksi produk sarana lesehan ini diperkirakan memakan waktu satu hingga dua minggu.

\section{Aspek Psikologi}

Pertimbangan aspek psikologi yaitu penganalisaan mengenai produk terhadap pengguna. Untuk itu, perancang sudah seharusnya mengenal dan memahami berbagai masalah yang berkaitan erat dengan calon pengguna produknya. Analisis yang berkaitan dengan aspek ini umumnya berkaitan dengan :

\section{A. Pengguna}

Target pengguna merupakan wanita dengan umur (18 tahun -25 tahun).

B. Warna

Warna memiliki peran penting dalam membangun persepsi dalam pikiran manusia. Persepsi tersebut dapat menimbukan reaksi yang bermacam. Untuk itu perlu dipertimbangkan pemilihan warna yang tepat untuk membangun persepsi agar sesuai dengan yang ingin dikomunikasikan. Untuk itu warna digunakan untuk mempertegas maksud dari suatu simbol.

Dalam proses perancangan ini penulis mencoba menampilkan kesan segar dan nyaman dengan menggunakan warna - warna comfort seperti putih, blossom, ungu, hijau kiwi, neon pink, abu - abu, coklat, merah paprika, biru dan lain sebagainya.

Namun dalam perancangan ini dipilih warna hijau. Hijau melambangkan alam. Warna hijau adalah warna yang mudah ditangkap mata dan dapat memperbaiki penglihatan. Warna hijau bersifat menenangkan, menyegarkan, dan mampu memperkuat rasa percaya diri. Warna hijau juga berarti kesehatan, keseimbangan, rileks, dan berjiwa muda. Dapat diartikan bahwa warna hijau mempunyai sifat keseimbangan dan selaras. Dalam sebuah 
ruang warna hijau melambangkan kesegaran dan kealamian sehingga akan memberikan ketenangan jiwa dan pikiran, serta menghilangkan penat dan stress.

\section{Aspek Lingkungan Kerja}

Pertimbangan aspek lingkungan kerja yaitu penganalisaan produk dari lingkungan kerja, keefisiensi produk saat digunakan di lingkungan kerja. produk yang dirancang merupakan produk yang efisien, karena produk ini saat tidak digunakan dapat disimpan dalam space yang terbatas, sehingga tidak mengganggu, mengingat produk yang foldable sehingga dapat disimpan dengan mudah.

Saat digunakan produk memang cenderung memakan tempat, diketahui bahwa saat dipakai ukuran produk bisa mencapai $120 \mathrm{~cm}$, sehingga memerlukan space yang cukup luas untuk memakai produk ini. Karena saat digunakan produk memfasilitasi hampir seluruh bagian tubuh yang digunakan saat melakukan posisi duduk lesehan.

\section{HASIL \& PEMBAHASAN}

\section{T.O.R (Term Of Reference)}

Term Of Reference adalah segala batasan yang berguna agar sesuai dengan apa yang diharapkan. Dalam proses perancangan ini TOR adalah sebagai berikut:

A. Pertimbangan produk

- Persepsi produk: Memiliki bentuk dan struktur produk yang nyaman dan memberikan rasa rileks.

- Tujuan produk: Produk yang dibuat berupa sarana pendukung lesehan untuk wanita kisaran umur 18 tahun - 25 tahun yang dapat memberikan kenyamanan saat melakukan aktivitas dirumah.

- Kondisi kerja: Produk bekerja sesuai dengan penggunaan, seperti membaca, menonton, belajar agar kondisi tubuh tidak cepat lelah.

B. Batasan produk

- Faktor kenyamanan: Memberikan keleluasaan atau ruang gerak yang maksimal dan penggunaan produk dapat mencakup segala sikap atau posisi lesehan.

- Faktor tempat: Tempat penggunaan produk adalah di lingkungan rumah, didalam rumah (indoor).

C. Deskripsi produk

- Target pengguna: Untuk wanita dengan kisaran umur 18 - 25 tahun yang melakukan aktivitas lesehan di dalam rumah.

- Ukuran produk: Ukuran produk secara umum menyesuaikan dengan data antropometri orang dewasa yang mencakup ukuran bagian tubuh yang digunakan dalam posisi duduk lesehan. Produk terdiri dari 4 bagian, dimana pada setiap bagian memiliki ukuran yang sama namun ada bagian yang mempunyai ketebalan yang berbeda.

- Material

- Busa (yellow dan sk (busa putih))

- Kulit Sintetik (oscar)

- Multipleks

- Stainless Steel

- Warna: Pertimbangan warna menggunakan warna hijau secara keseluruhan dan finishing stainless steel. 


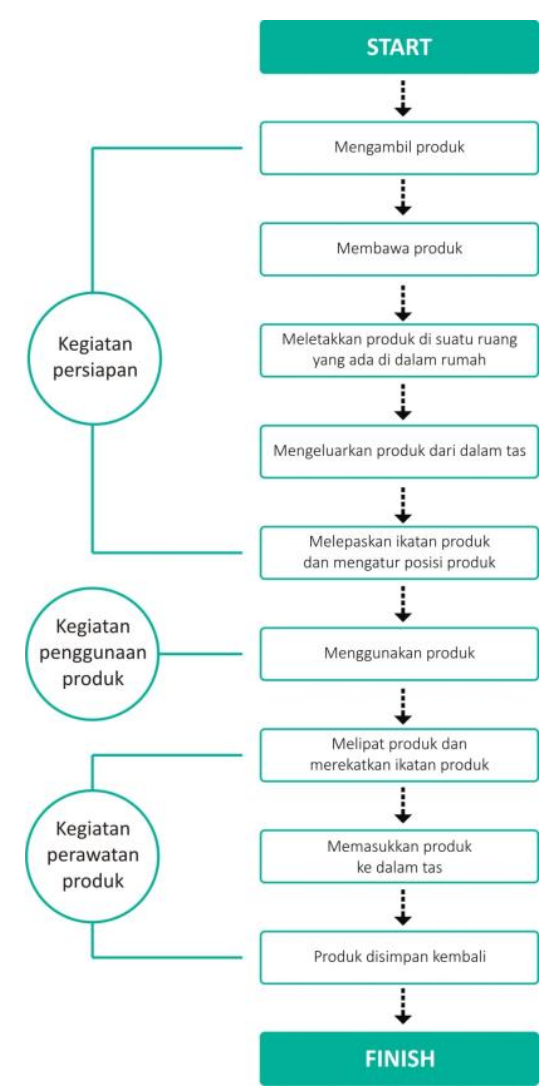

Gambar 4.4 Flow of Activity (FOA)

(Sumber: Dokumentasi Pribadi, 2015)

\section{Brief Design}

Pada sub bab ini akan dijabarkan mengenai proses perancangan atau visualisasi produk hingga menghasilkan final desain. Berikut poin-poin yang akan diterangkan . Dalam proses pembuatan studi model terdapat beberapa tahapan yang dilakukan yaitu sebagai berikut :
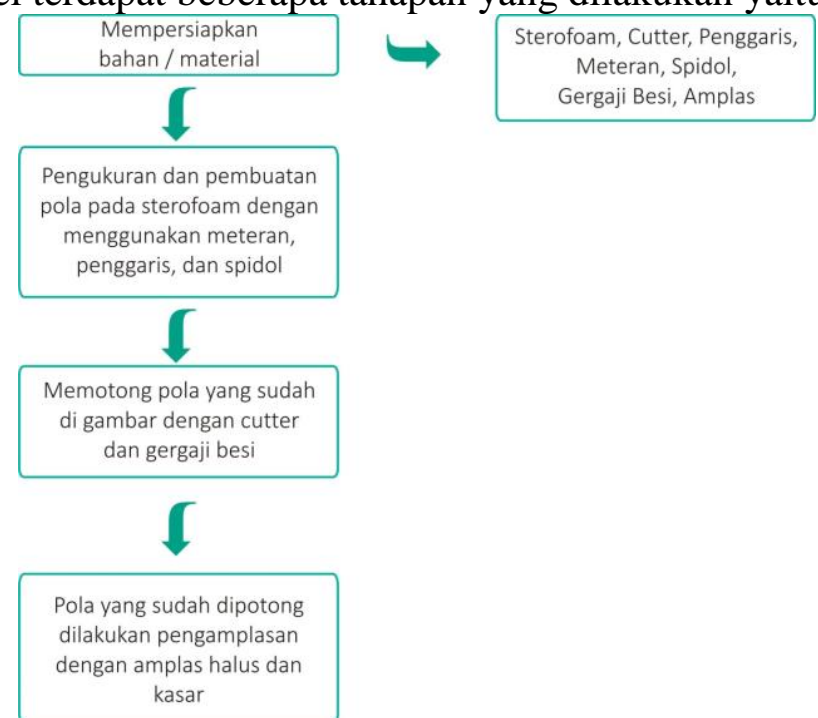

Gambar 4.10 Tahapan studi Model

(Sumber: Dokumentasi Pribadi, 2015) 


\subsubsection{Operasional}

Berupa visualisasi operasional penggunaan produk yang dirancang. Pada perancangan ini terdapat tiga operasional yaitu proses mempersiapkan penggunaan produk, membawa produk, dan proses menggunakan produk pada saat melakukan aktivitas makan.

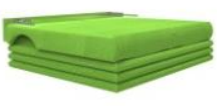

Produk dalam keadaan normal

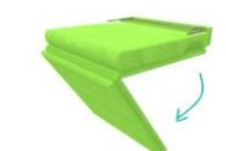

Produk dibuka dari bagian ke - 2 antara dudukan dan alas bawah

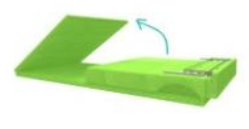

Pembukaan lipatan (alas bawah)

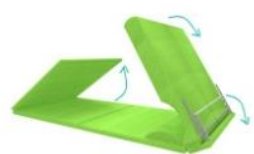

Pembukaan lipatan (alas bawah dan sandaran dan selanjutnya bagian penahan

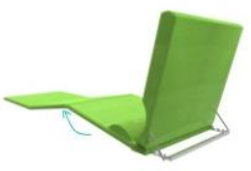

Produk siap untuk digunakan dan diatur sesuai kenyamanan

Gambar 4.11 Operasional

(Sumber: Dokumentasi Pribadi, 2015)

\subsubsection{Final Render}

Berupa visualisasi produk secara keseluruhan untuk menginformasikan bentuk dan warna produk.

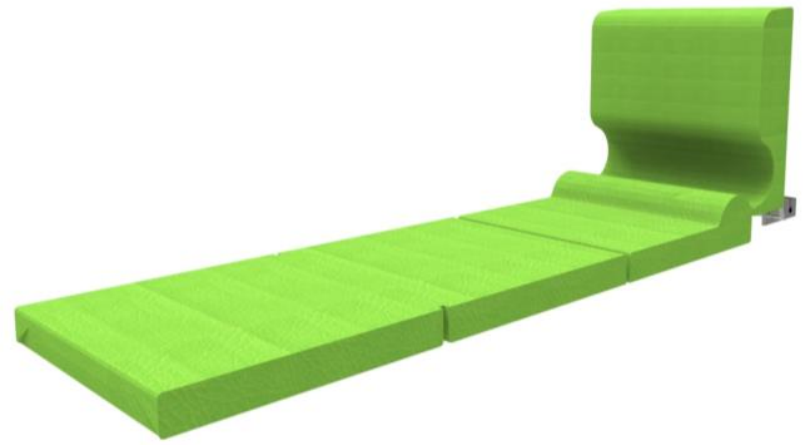

Gambar 4.12 Final Render 1

(Sumber: Dokumentasi Pribadi, 2015)

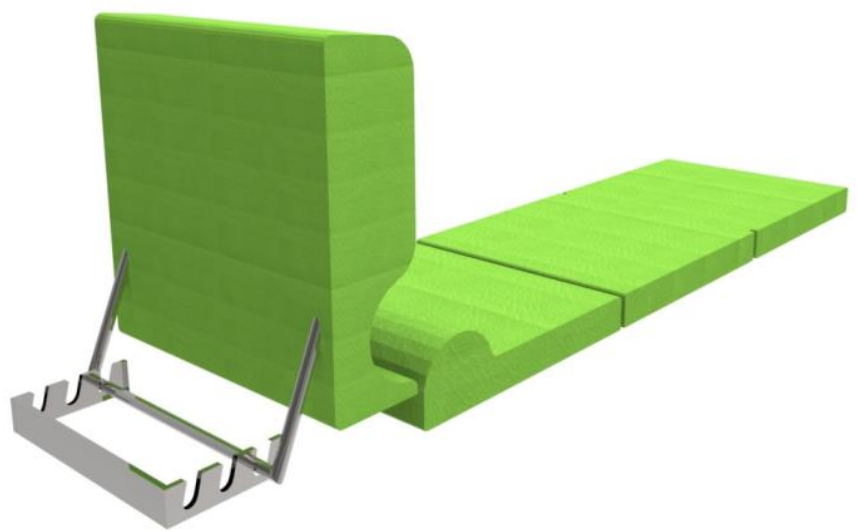

Gambar 4.13 Final Render 2

(Sumber: Dokumentasi Pribadi, 2015)

\section{KESIMPULAN}

Berdasarkan latar belakang, diketahui bahwa lesehan merupakan budaya yang menunjukkan sifat kesederhanaan, kesetaraan, dan kebersamaan yang didasarkan pada rasa persaudaraan. 
Istilah lesehan yaitu cara duduk di atas lantai, dengan posisi duduk yang alternatif yang biasa dipakai sehari - hari saat di rumah, karena lesehan dianggap lebih bebas dan menyenangkan. Saat dirumah banyak aktivitas yang dapat dilakukan dengan posisi duduk ini, namun disisi lain banyak pula resiko yang diakibatkan dari posisi duduk ini.

Kesimpulan dalam penelitian dan perancangan ini adalah sebagai berikut :

1. Perancangan sarana pendukung lesehan ini tidak lepas dari penganalisaan masalah yang timbul yang diakibatkan dari posisi duduk lesehan.

2. Perancangan ini mempertimbangkan aspek ergonomi sebagai dasar dari perancangan.

3. Perancangan ini juga memperhatikan aspek antropometri untuk menunjang kenyamanan produk, baik dari segi ukuran produk dan ukuran target penggunanya.

4. Perancangan ini bertujuan untuk mengatasi keluhan - keluhan yang dirasakan pengguna posisi duduk lesehan dalam penggunaan jangka waktu yang lama, posisi duduk ini membuat penggunanya cenderung kurang nyaman, resiko yang diterima jika terlalu lama menggunakan posisi duduk ini seperti rasa tidak nyaman, pegal, kesemutan, kesulitan berdiri akibat dari terlalu lama duduk, sakit punggung, dan sesekali ingin bersandar untuk menghilangkan rasa pegal.

5. Perancangan ini memperhatikan hampir semua bagian tubuh yang menjadi tumpuan ketika duduk lesehan, mulai dari punggung hingga ujung kaki, sehingga diharapkan hasil dari perancangan ini dapat membuat pengguna posisi duduk lesehan dapat lebih nyaman dan dapat mengatasi keluhan - keluhan yang pengguna rasakan.

6. Perancangan ini memperhatikan warna yang akan digunakan pada produk, karena diketahui warna dapat mempengaruhi perasaan pengguna, dalam perancangan ini dipilih warna hijau. Hijau melambangkan alam. Warna hijau adalah warna yang mudah ditangkap mata dan dapat memperbaiki penglihatan. Warna hijau bersifat menenangkan, menyegarkan, dan mampu memperkuat rasa percaya diri. Warna hijau juga berarti kesehatan, keseimbangan, rileks, dan berjiwa muda. Dapat diartikan bahwa warna hijau mempunyai sifat keseimbangan dan selaras. Dalam sebuah ruang warna hijau melambangkan kesegaran dan kealamian sehingga akan memberikan ketenangan jiwa dan pikiran, serta menghilangkan penat dan stress.

7. Perancangan ini memperhatikan penggunaan material yang digunakan dengan kriteria ringan, kuat dan material yang mudah dibersihkan.

8. Secara sistem, perancangan ini menggunakan sistem foldable yang bertujuan untuk memudahkan dalam penyimpanan yang didukung dengan sistem pemasangan magnet pada bagian - bagian tertentu dari produk untuk memperkuat sistem foldable yang diterapkan, serta sistem dari sandaran produk yang mudah untuk diubah demi kenyamanan pengguna dan penambahan sebuah bantalan untuk kaki dengan system lepas pasang, sehingga bisa digunakan dan disimpan jika tidak digunakan.

\section{DAFTAR PUSTAKA}

[1] Wignjosoebroto, Sritomo. 2003. ERGONOMI (Studi Gerak dan Waktu). Surabaya : Guna Widya.

[2] Nurmianto, Eko. 2008 . Ergonomi, Konsep Dasar, dan Aplikasinya. Surabaya, Guna Widya.

[3] Panero, Julius dan Zelnik, Martin. 2003. Dimensi Manusia \& Ruang Interior . Jakarta : Erlangga. 
[4] Creswell, John W. 2014 . Research Design . Yogyakarta : Pustaka Pelajar.

[5] Windura, Sutanto. 2009. Minp Map Brain Management Series. Jakarta : PT. Elex Media Komputindo.

[6] Palgunadi, Bram. 2008. Disain Produk 1 (disain, disaner, dan proyek disain). Bandung : ITB.

[7] Palgunadi, Bram. 2008. Disain Produk 2 (analisis dan konsep disain). Bandung : ITB.

[8] Palgunadi, Bram. 2008. Disain Produk 1 (aspek-aspek desain). Bandung : ITB.

[9] Nugroho, Eko. 2008. Pengenalan Teori Warna. Yogyakarta : Andi Publiser.

[10] Yassierli dan iridiastadi, Hardianto. 2015. Ergonomi Suatu Pengantar. Bandung : Remaja Rosdakarya.

[11] Kuswana, Wowo Sunaryo. 2015. Ergonomi \& K3: Kesehatan Keselamatan Kerja. Bandung : Remaja Rosdakarya.

[12] Santoso, Gempur. 2004. Ergonomi, Manusia, Peralatan dan Lingkungan . Jakarta : Prestasi Pustaka Publisher.

[13] Swasty, Wirania,(2010), A-Z Warna Interior Rumah Tinggal, Jakarta : Penebar Swadaya - Griya Kreasi. 